\title{
THE SOUNDS OF WHITMAN: A COMPOSER'S VIEW
}

\author{
CARYN BLOCK
}

THE ROLE OF MUSIC in Whitman's life and the effect that Whitman's poetry has had on the musical settings of composers for more than a hundred years bespeak an interdependent relationship. Justin Kaplan maintains that no other American poet has had his poetry set to music so often by so many different composers with such satisfactory results. ${ }^{1}$ Indeed, more than 150 composers have produced over 1200 settings of Whitman's poetry, with more than 400 settings specifically written for voice and piano. Whitman's free verse, with its natural sense of flow and feeling and few formal constraints, has been considered excellent material for song settings by nineteenth- and twentieth-century composers of different nationalities, including American, British, French, Italian, German, Dutch, Russian and Norwegian. ${ }^{2}$ These composers have used a variety of languages and harmonic styles - the tonal and modal vein, atonality, the twelve-tone method, and computer music applications. Each of the American composers I have chosen for discussion possesses a unique harmonic language; their voices and settings reflect their own understanding of the poems, and together represent one of Whitman's richest legacies.

Ned Rorem (1923- ), an American composer, writer, and diarist, has set many poems from Leaves of Grass and prose from Specimen Days to music in various forms and styles over the course of four decades. Because Rorem loves form, he is attracted to Whitman's style, or "lack of style," a free verse that allows for unlimited musical variety, and has remarked that "Whitman is content and a poet's content is a musician's form." "In his Nantucket Diary he similarly notes that he has turned to Whitman for decades since "he had purveyed my most heartfelt texts," suggesting that he has adopted Whitman for his meaning, not for his sound. ${ }^{4}$ Rorem's Look Down Fair Moon, written in July 1957 in France, is a very brief song setting, but most effective in its capacity to paint a haunting, poignant impressionistic picture. The poem of four lines is in Drum-Taps: 
Look down fair moon and bathe this scene,

Pour softly down night's nimbus floods on faces ghastly, swollen, purple,

On the dead on their backs with arms toss'd wide,

Pour down your unstinted nimbus sacred moon. ${ }^{5}$

In his song, Rorem attempts to portray musically Whitman's images of the moon bathing a death scene during the Civil War-images meant to symbolize the shadow of death and eternal peace. Structurally designed as a miniature form of only four phrases (A A' B A'), the lines are tightly interwoven for a very concentrated effect. Cast in a very slow tempo, the opening of this tonal work in $\mathrm{E}$ minor is soft with the voice and piano entering almost simultaneously to paint a portrait of death. Phrases one and two are linked by virtue of their similar melodic and harmonic material mirroring Whitman's prosody of parallelism. The descending theme of phrase one is presented in the vocal line over the course of two measures. When the melodic material returns to fashion phrase two, it is modified by way of contraction and expansion, intensifying and gradually increasing in length to three measures. The piano accompaniment repeats five successive times to create a static, ethereal feel, until the powerful climax, which occurs in the third musical phrase. Excellent use of word painting (that is, the technique developed in the Renaissance and Baroque periods in which certain words or phrases of the text are inflected with a specific musical representation) may be found throughout the song:

1. "Look down, fair moon" (Measure 1)-A descending melodic line is used to portray the lovely moon shining down on the scene of death:

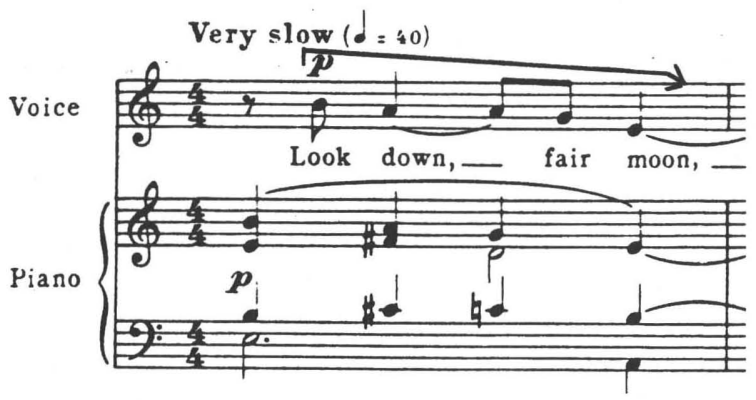


2. "and bathe this scene" (Measure 2)-There is a slight rise that then descends in a large leap down as if descending into water:

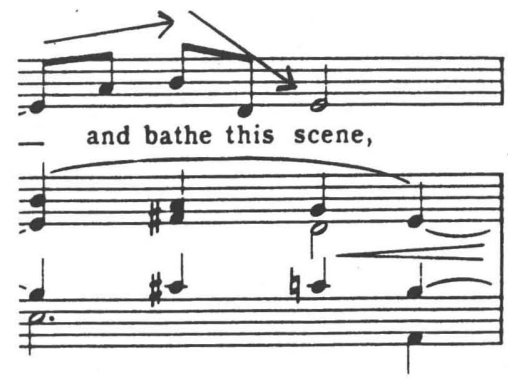

3. "Pour softly down night's nimbus floods on faces ghastly, swollen, purple" (Measures 4 \& 5) - Two accents are placed on the words "faces ghastly," the first a rhythmic syncopation and the second in the form of an accent mark on the same note. On the word "swollen," a longer note value in syncopation is employed to impart meaning and accentuate the word. And on "purple," the composer assigns the same two types of accents as before, but now at the interval of a minor third higher for further emphasis:

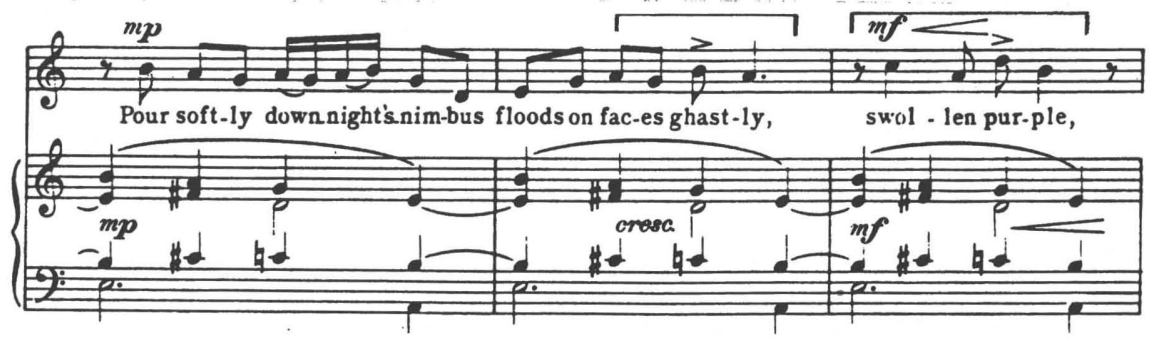

4. Contrasting Section B, featuring the climax: "On the dead on their backs" (Measures $7 \& 8$ ) - The voice and piano begin simultaneously, the only occurrence of this in the song. They are at the forte dynamic level, with the marking appassionata (passionately), and the voice is high in its range. The piano part underneath continually ascends by quarter notes - an effect that mirrors the vocal high points; as it reaches the goal of its ascent, it becomes more chromatic for intensity. The vocal line reaches its pinnacle on the words "arms toss'd wide," a feat accomplished by reaching the highest note two times and by a broad melismatic treatment of the word "wide," which depicts the expanse of outstretched arms. This effect is heightened further by crescendo and decrescendo markings for nuanced effect and emphasis: 


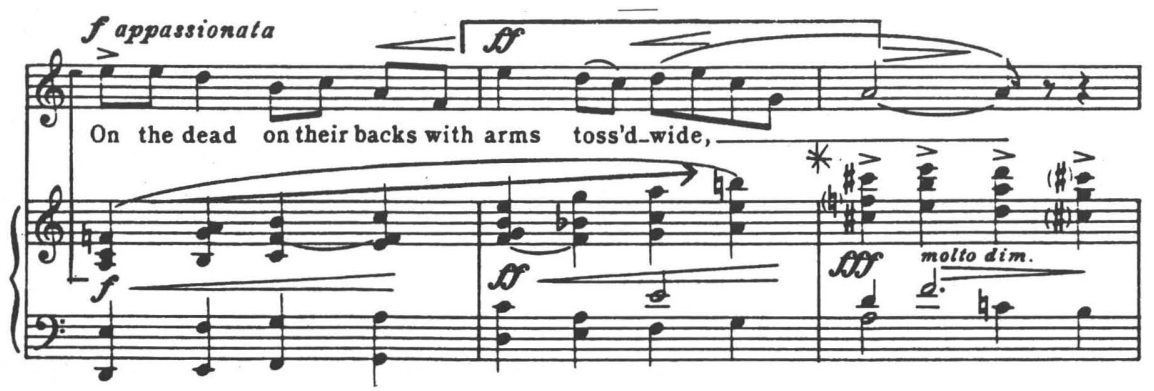

In this haunting setting, Rorem is able to evoke the pain and passion of Whitman's poem on the Civil War. Through a soft, ethereal musical translation that grows to a dramatic climax, he portrays the delicate balance of life that the poem is about.

Vincent Persichetti (1915-1987), another eminent American composer, who was a pianist, conductor, writer, and teacher at the Juilliard School, also interpreted Whitman's verbal art in his musical setting of it. Persichetti's Celebrations for Chorus and Wind Ensemble, commissioned by the Wisconsin State University at River Falls, was written in 1966 and stands as an excellent example of a moving and evocative large-scale choral setting of nine of Whitman's poems. Warmth and joy pervade the score musically, as the settings allow the words to flow naturally. Persichetti was undoubtedly attracted to the themes, language, and rhythm of Whitman's verse, for these are elements that are continually brought out from one movement to the next. The overall progression is from slow, delicate settings to more rapid ones, finally working up to the climactic ninth movement, The Voyage. "I Celebrate Myself" is a joyful setting of the first five lines of the first section of Whitman's "Song of Myself" in a fast tempo marked resoluto (resolute). Persichetti uses for this movement a modified ternary form (A B a') that mirrors the basic form of Whitman's five lines (with the addition of a short recapitulation of the poem's first line to create Section a'). This technique of repetition allows him to close his form for emphasis and balance, rather than continue on to the next stanza. The explosive opening of the brass and woodwinds in $\mathrm{F}$ minor introduces the memorable material of Section A that will be used continuously throughout the setting, either intact or in fragments. The motive itself is comprised of a series of unaccented tones leaping to an accented perfect fourth, then to a perfect fifth, and finally to a major sixth, against which a descending scalar line is played.

The integration of the various voices is one method Persichetti has of bringing forth the special meaning of the text - that is, the common- 
alities between people. The brass and woodwinds are joined by the full chorus on "I celebrate myself" in two distinct parts: soprano and tenor on the same pitch an octave apart, and alto and basses on the same tone, also an octave apart. They sing the same motive first heard in the wind ensemble, a perfect fifth leap up to E flat, now repeating it two more times (for emphasis) for each of the syllables in the word "celebrate." They then sing the expanded form of the motive, arriving a step higher on a major sixth to paint the word "self" on a lengthy five beat note. By choosing to emphasize words such as these with higher tones and longer note values, Persichetti skillfully brings forth the meaning of Whitman's words. This pattern may be seen frequently throughout the movement:

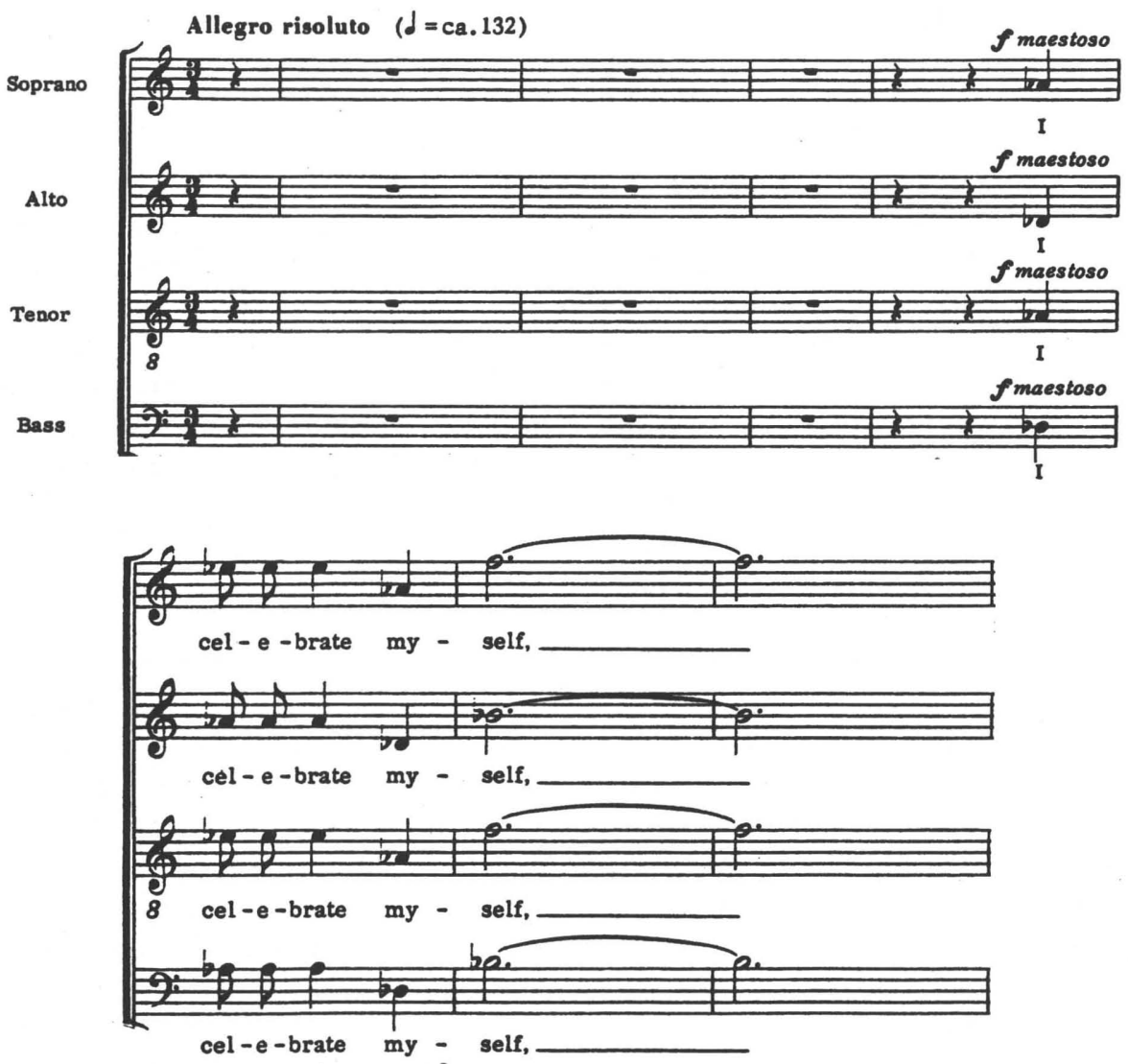

(Measures 1-7)

Persichetti makes excellent use of word painting throughout the work with vocal range and choice of register. The line "For ev'ry atom belonging to me as good belongs to you," unlike before, is sung at uni- 
son for all four voices, an element that provides unity and expresses Whitman's sense of his sympathetic attachment to others. This vocal setting is assigned a rather low tessitura with a lower dynamic level, and thus provides contrast to the earlier music. The very narrow range of the vocal parts serves to "narrow" the gap between one person and another and crystallize the concept that we are all part of one human family:

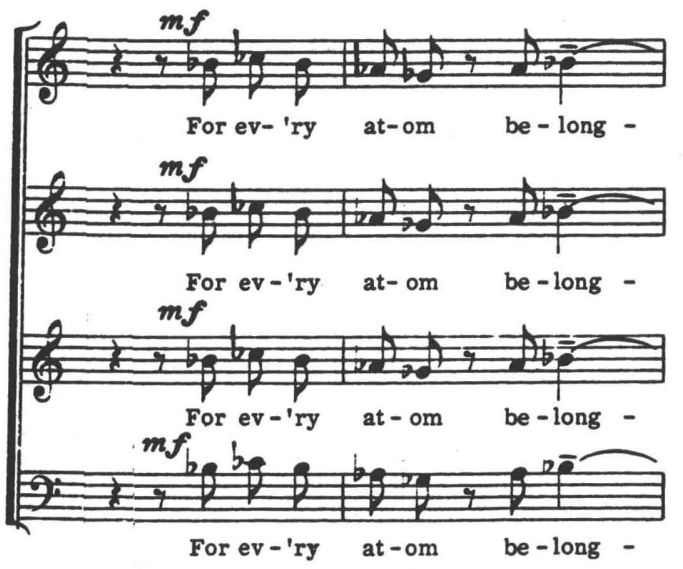

(Measures 17-18)

Another example of the technique of word painting may be found in the passage that follows, where the alteration of vocal range is coupled with rhythmic accentuation. A brief contrasting Section B, played by a brass choir expressively, begins, followed by the altos, who enter softly on the words "I lean and loafe" marked con calma (calmly). The low tessitura of this vocal line not only establishes a marked contrast to the high register of the earlier brass section; it presents a gentle, calmer mood. To bring to life the word "lean," the composer accentuates the note with a rhythmic stress-a longer note value and metric accent. The dynamic level is brought down to piano, and the expression for the line "a spear of summer grass" is indicated by the marking dolce (sweetly):
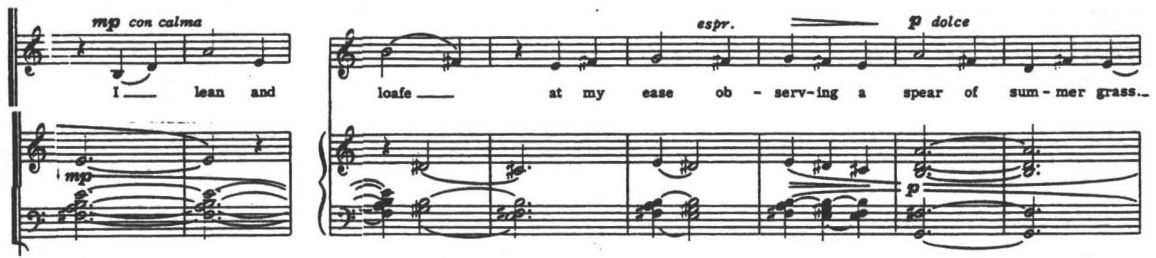

(Measures 32-39) 
The return of Section a' illustrates another technique Persichetti adopted for this setting-modified repetition through variation. The notes forming the perfect fifth interval on the words "and sing" are repeated on the words "myself" to a higher goal pitch of the greatest length in the entire piece. Against this fortissimo climax, a full statement of the opening brass motive is expressed for the final time, and the last figure, a fragment of the motive, mirrors the setting's opening, but now with interval modification - the whole gesture a varied repetition.

In this composition Persichetti captures the tone and feeling of vitality and exuberance in Whitman's lyric. At the same time, the setting expresses the essence of Whitman's spirit and message-adventurous and future-oriented. The composer's skillful craft enables these qualities to be conveyed in a work of great openness, warmth, and joy.

In 1970 Roger Sessions (1896-1985), co-founder of the famed Copland-Sessions new music concerts in New York, composed a moving, dramatic cantata setting of Whitman's elegy for Lincoln, "When Lilacs Last in the Dooryard Bloom'd," a setting commissioned by the University of California at Berkeley to commemorate its 100th anniversary and dedicated "To the memory of Martin Luther King, Jr., and Robert F. Kennedy." The work exemplifies the twentieth-century atonal style, with the musical language rooted in the twelve-tone tradition, expressionistic in quality; it is contrapuntal, with different musical levels and deeper structural levels at work that suggest the various levels of meaning in the text. Gay Wilson Allen observes that Whitman's poem "exhibits a beautiful symmetry of imagery, rhythm and pattern of symbols." In it Whitman articulates a philosophy of death through three main symbols or motifs: 1) the drooping star, representing the slain president; 2) the blooming lilac, a metaphor for the poet's tribute; and 3) the bird, symbolizing the voice of reconciliation, the acceptance of "sane and sacred death."7 According to Kaplan, Whitman, well-versed in musical forms, developed these symbols in a fashion nearly analogous to sonata form, with their exposition, development and transformation, and recapitulation. ${ }^{8}$ Part 1 , introductory in nature and quite short, presents the three symbols. Part 2 constitutes a vivid description of the funeral journey, including the visible signs of grief (public outpouring and pageantry). Part 3 represents the culminating point of the poem - contemplation of Death - and highlights a carol that is not only the focus of this section but of the cantata and the entire poem. ${ }^{9}$

Sessions skillfully uses the various breaks between the stanzas of Whitman's poem to change the musical forces and create variety; he moves fluidly from one soloist to another, from soloist to chorus, and from chorus to orchestra in an effort to underscore the dramatic text- 
an elegy that exhibits contrasts in tone for the various stages (or signs) of grief by a nation in mourning. By assigning certain musical motifs to the symbols of the poem-and repeating them throughout the workhe is able to unify the continuum of sound through the various sections and reenact the content of the poem, what Charles Feidelson has termed "the duality of life and death," in which contrasting "symbols behave like characters in a drama." 10 The first motif, representing the lilacs and star, is heard prior to the opening soprano solo and continues as she sings; the second motif, the bird's song, is heard as a fast flurry of notes played by the flute and piccolo:

\section{Part 1 - Two Symbols}
A. Lilac and Star:

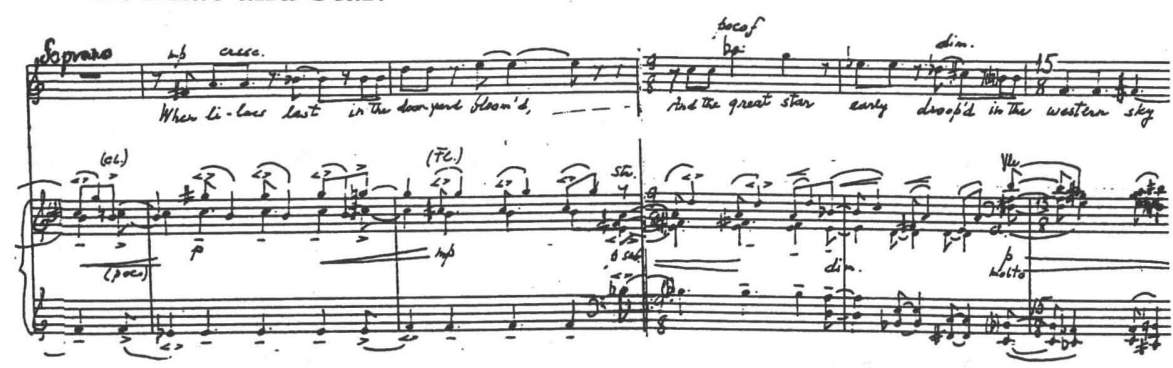

(Measures 4-8)

B. Bird Song:

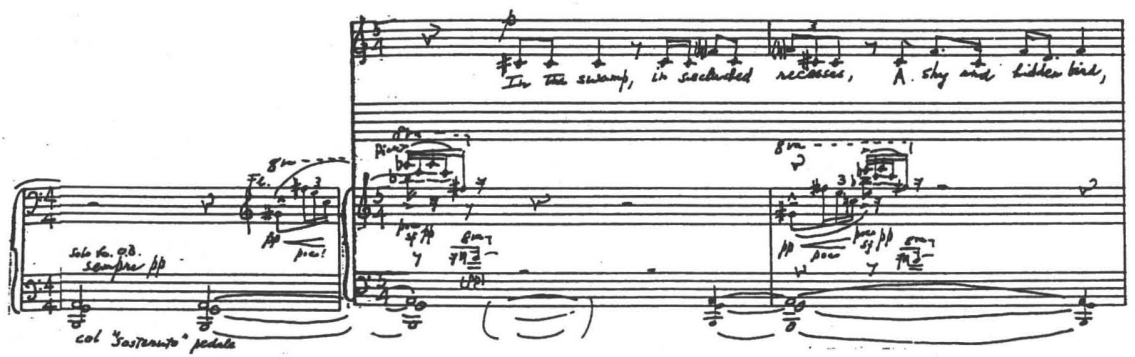

(Measures 61-63)

Part 2-Development Section: Funeral journey:

Alternating seconds depict the slow progression of the coffin on the funeral train; introduction of chorus: 

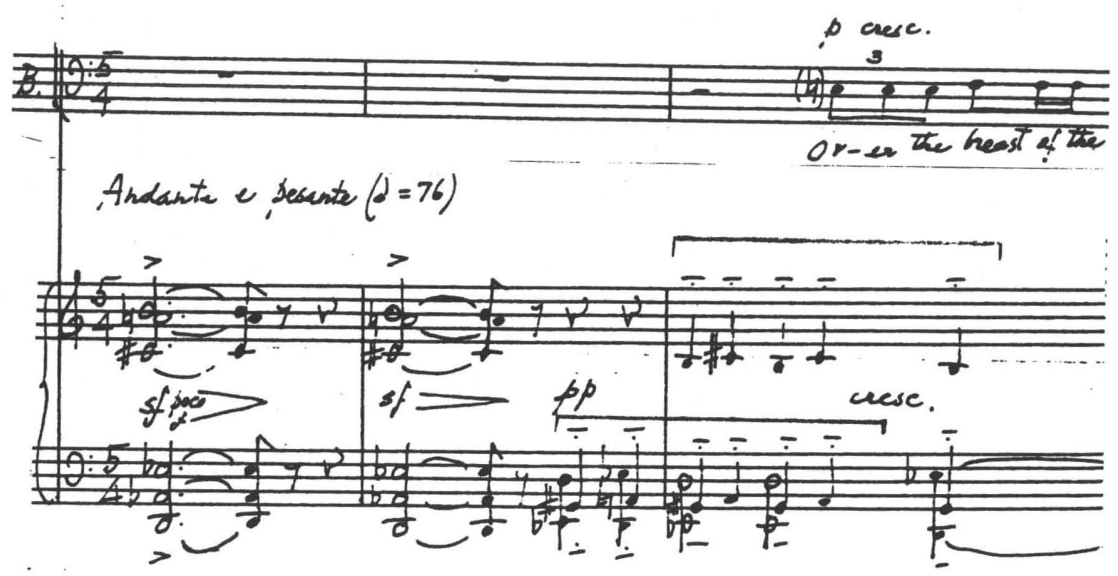

(Measures 81-83)

A. "Tolling, Tolling Bells"-Dramatic Choral Moment: High, accented bell-tones:

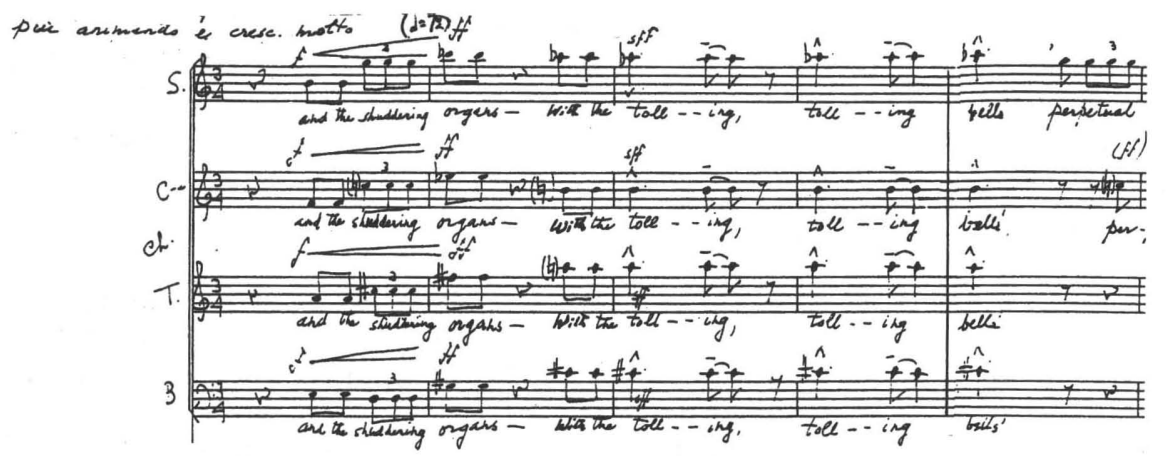

(Measures 128-132)

B. Baritone solo ("Sing-On! sing on, you gray-brown bird!") couples a birdsong-likemelody drawn from the earlier alternating seconds with the bird motif from the exposition again played by the flute, symbolic of the bird. This contrapuntal representation of the musical materials in the orchestra illustrates the way in which Sessions translates Whitman's meaning into sound: 


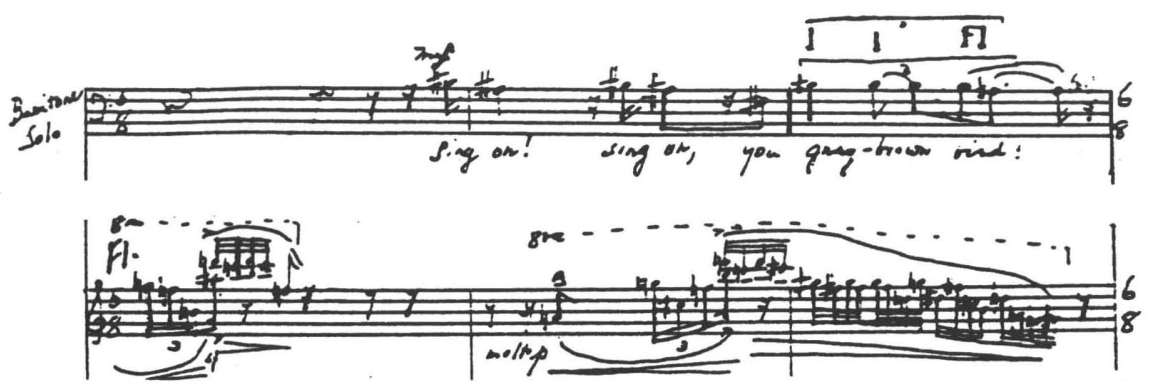

(Measures 297-299)

Part 3-Recapitulation:

A brief orchestral interlude at an Adagio tempo leads to impassioned Baritone solo, "Carol of Death." This section features an extended carol for Mezzo-Soprano, "Come, lovely and soothing Death."

In his cantata setting of "When Lilacs Last in the Dooryard Bloom'd," Sessions creates a stirring tribute to the slain Robert F. Kennedy, Jr., and Martin Luther King, Jr., through sensitive treatment of the various tones of grief, sorrow, and acceptance depicted in Whitman's poem and deft handling of tension and relaxation in his unique harmonic language. Striking orchestration and treatment of the vocalists serves to delineate the more dynamic sections of the text, allowing Sessions to elicit the full emotional power and range of Whitman's poem in a dramatic statement at turns majestic, delicate, and bitter.

My own experience setting Whitman's poems to music has been for voice and chamber ensemble and voice and piano. I was attracted to his poems for their originality, their universality, their variety of moods and emotions, their dynamic sense of rhythm and cadence (and lack of rhyme), and their montage-like imagery. From Montauk Point, my threemovement setting of "From Montauk Point" (1888) and "You Tides With Ceaseless Swell" (1885), two of Whitman's poems about the sea that contrast in tone, pacing, and rhythm, was commissioned in 1990 by Herbert and Ethel Koslow of Wyndmoor, Pennsylvania for flute, bass-baritone, cello and piano. The work was arranged in 1997 for flute, clarinet, horn and bassoon. The unique timbral qualities of the colorful woodwind quartet approximate characteristics found in the original scoring. The musical material of the original version was redistributed so that the warm horn replaced the baritone voice, the bassoon assumed the lower lines, the flute still maintained its former role, and the B Flat clarinet was assigned the material formerly given to the right hand of 
the piano. In the third movement, I have designated a clarinet in $\mathrm{A}$ for a timbral change.

At the outset I decided on a three-movement work where the first and third movements would be settings of the Whitman texts for baritone and chamber ensemble that frames a middle instrumental movement. Thus, an arch is formed, whose center is an interlude. I selected for this internal movement the form of the cantilena-a composition that involves a vocal melody of a lyrical nature. The contrast has been achieved in the woodwind version by reducing the texture to only three instruments-flute, bassoon, and horn.

The poem "From Montauk Point" suggests the interrelation of man and nature, so awesome in expanse, with the image of the "wild unrest" of the "curling" wave-caps symbolizing the unrest of man's soul, which constantly seeks the new and unknown. The challenge was to create an evocative setting of a text that was replete with concrete images but also encompassed this spiritual meaning (613). I chose to use tangible, symbolic musical motifs to suggest more spiritual or metaphysical ideals and, whenever possible, to weave and develop them in such a way as to form a unified composition through the technique of organic development. Counterpoint is another vital aspect of this movement, since I believe the poem speaks to the concept of multiple life forces occurring simultaneously - the sea, the sky, the eagle's flight, and man's presence "absorbing" it all. This sense is conveyed in musical terms by composing different types of music for four distinct layers of sound, for the unique timbral qualities of the woodwinds. Once this assemblage was in place, I wove a tapestry of sound via counterpoint - the voices entering, eliding, concluding at different points. The continuum of sound was intended to be a metaphor for the momentum of the sea, and the restless quest of man's spirit to fathom the universe.

The form of the work follows loosely Whitman's quintet. Although it has a continuous feel to it, much like the poem itself, where the lines unfold naturally, in actuality I have designed subsections to delineate the different moods of the poem. Overall, it is a large ternary form (A B $\left.A^{\prime}\right)$. The Third Section (A') functions both as a brief recapitulation of thematic material heard in A and a coda to balance out the movement. The title (From Montauk Point) is not only the name of the first movement, but also presents the situation of the entire setting - a view to the sea from a coastal point. I was interested in creating a special mood at the very beginning of the work, setting the stage for the solo horn entrance and giving a sense of the undulating waves and rhythm of the sea. I repeated words of the text for purposes of musical phrasing and emphasis and have highlighted choice words through word-painting:

1. A wave-like undulation of regular triplets for the clarinet and a moving bass line for the bassoon for momentum. The reed instruments 
together create a somewhat "salty" or"dark" sound like the churning sea.

2. Initial use of the open interval of a perfect fifth to evoke the expanse of the sea:

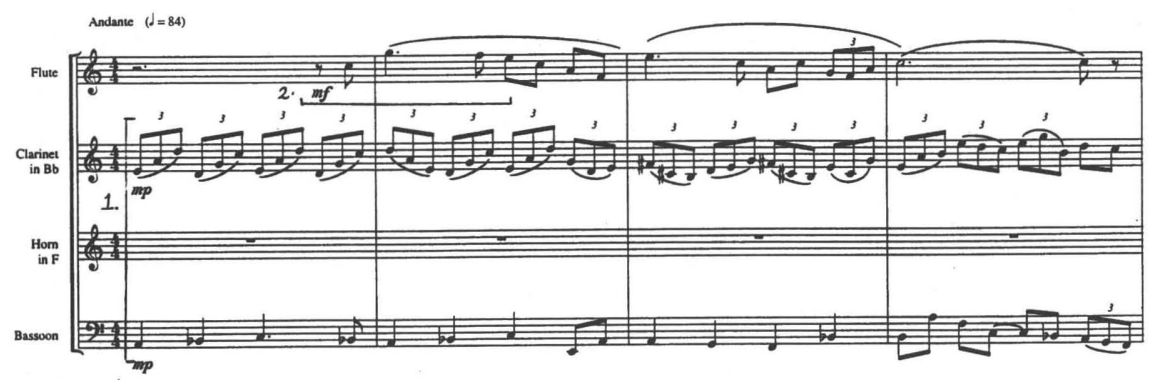

(Measures 1-4)

3. Theme B features a fast succession of notes to illustrate "The tossing waves, the foam," and I have literally tossed the theme around to the various instruments:

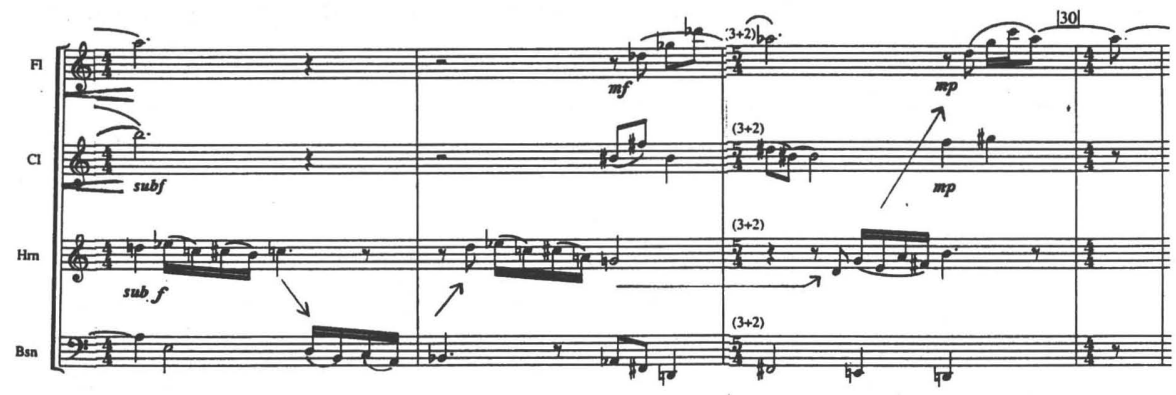

(Measures 27-29)

4. In contrast, at slower tempo Meno Mosso, softer dynamics portray "the ships in the distance" with presentation of new Theme Csyncopated, fairly level in contour, to suggest the level plane of the horizon. Motive and text repeat for emphasis:

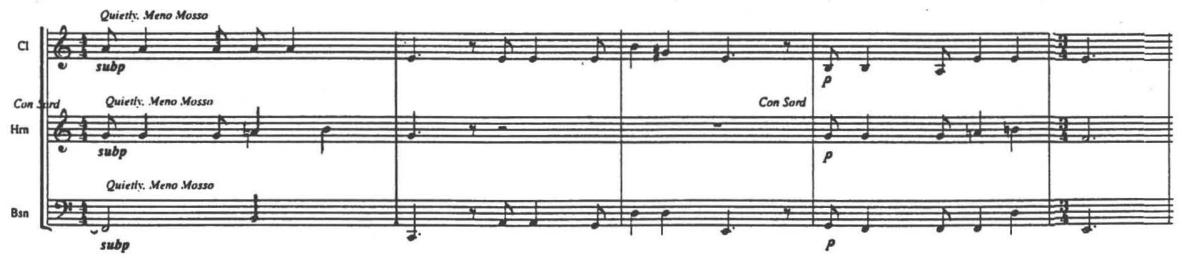

(Measures 33-37) 
5. Climax of movement is written for full ensemble at forte dynamics for line "The wild unrest, the snowy, curling caps." I have employed active counterpoint between the instruments, a high range for the horn, an accelerando and increasing dynamics:

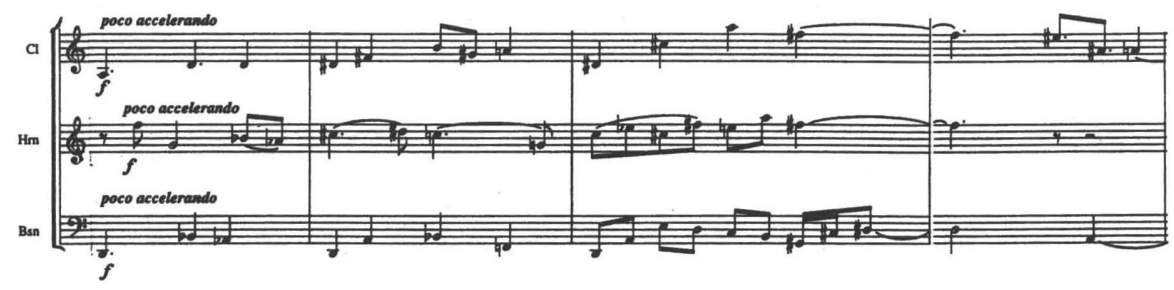

(Measures 46-49)

"From Montauk Point" and "You Tides with Ceaseless Swell" greatly appealed to me, as each poem is so evocative and ripe with images reminiscent of the rhythm and music of the sea. Moreover, certain ontological concerns of the twentieth century are anticipated by Whitman in these poems, allowing me to bring a deeper psychological meaning to the musical context. It is my hope that the melding of my particular harmonic language with Whitman's text has enhanced and brought a richness to his poetry for new audiences.

The challenge for composers seeking to set Whitman's work to music is to bring forth the depth of meaning in that work using an art that is symbolic and, for the most part, abstract. The unique musical voices of the composers I have discussed shed light on Whitman's writings, offering new ways to perceive the poet's words. Whitman's carol from "Proud Music of the Storm" gloriously sings of this extraordinary relationship between music and poetry, and seems to beckon musicians of all types to perpetuate his vision of the future by combining the two:

Composers! mighty maestros!

And you, sweet singers of old lands, soprani, tenori, bassi!

To you a new bard caroling in the West,

Obeisant sends his love. (529)

Philadelphia, Pennsylvania 


\section{NOTES}

1 Justin Kaplan, "Whitman and Music," in Roger Sessions's album When Lilacs Last in the Dooryard Bloom'd (New York: New World Records, 1977).

2 Thomas Hampson and Carla Maria Verdino-Sullwold, "Walt Whitman and Song," n.p., in Thomas Hampson compact disc To the Soul (New York: EMI Classics, 1997).

3 Ned Rorem, Settling the Score: Essays on Music (New York: Harcourt, 1963), 312.

4 Ned Rorem, The Nantucket Diary of Ned Rorem (San Francisco: North Point Press, 1987), 523-524.

5 Walt Whitman: Complete Poetry and Collected Prose, ed. Justin Kaplan (New York: Library of America, 1982), 453. Hereafter references to this edition will appear in parentheses in the text.

6 Leaves of Grass, ed. Gay Wilson Allen (New York: New American Library, 1958), x.

7 Kaplan, "Whitman and Music."

8 Kaplan, "Whitman and Music." Although the poem itself has a formal construction of sixteen sections, the architecture of the cantata is in three major sections.

9 These descriptions of the parts of the composition are informed by Michael Steinberg's liner notes in the Roger Sessions album When Lilacs Last in the Dooryard Bloom'd.

10 Charles Feidelson, Symbolism and American Literature (Chicago: University of Chicago Press, 1953), 22.

\section{Musical Credits:}

Block, Caryn. "From Montauk Point II" for Flute, Clarinet, Horn and Bassoon. Encore Chamber Players in concert, October 1997, Philadelphia Score and tape available through the American Music Center, 30 West 26th Street, Suite 1001, New York, New York (Tel: 212/366-5260)

Persichetti, Vincent. "Celebrations" for Chorus and Wind Ensemble from CELEBRATIONS. [CD of IUP Wind Ensemble and Chorale, Jack Stamp, conductor]. San Juan Capistrano: Citadel, 1995.

Rorem, Ned. Songs: "As Adam Early in the Morning”, "Look Down Fair Moon" from TO THE SOUL. [Thomas Hampson, Baritone and Craig Ruttenberg, Piano]. New York: EMI Classics, 1997.

Sessions, Roger. "When Lilacs Last in the Dooryard Bloom'd" [Boston Symphony Orchestra, Seiji Ozawa, conductor; with the Tanglewood Festival Chorus, John Oliver, conductor]. New York: New World Records, 1977. 